\title{
“Only your labels split me": epistemic privilege, boundaries, and pretexts of 'Religion'
}

\section{Dr. Lilith Acadia ${ }^{1}$}

“Only your labels split me."

- Gloria Anzaldúa ${ }^{2}$

"[W]ords create worlds, especially those categories that order dominant discourses."

— Timothy Fitzgerald ${ }^{3}$

“[T]here's an enormous amount of damage done around the world in the name of religion and certainty."

- Barack Obama ${ }^{4}$

"I assert most unhesitatingly, that the religion of the South is a mere covering for the most horrid crimes,- a justifier of the most appalling barbarity,- a sanctifier of the most hateful frauds, —and a dark shelter under which the darkest, foulest, grossest, and most infernal deeds of slaveholders find the strongest protection."

— Frederick Douglass ${ }^{5}$

Like the unmapped globe, the individual has no borders until identity categories delineate political lines dividing up what was previously a unique, unified whole. Gloria Anzaldúa describes this imposition of borders on an intact "me," whom "[o]nly your labels split." The labels are imprecise, ill-fitting identity categories of gender, race, class, and politics that belong to someone else. She rejects the suggestion that such an identity assemblage makes her "confused" or "[a]mbivalent," because the borders are foreign to her otherwise unbroken self: label confusion does not imply identity confusion. Identity categories are the kinds of concepts that those with political and epistemic power use to draw borders on individuals and maps, to 
impose distinctions and hierarchies suiting their objectives, to "create worlds" with words to “order dominant discourses," as Timothy Fitzgerald explains. The powerful can then apply those concepts and the worlds they create to discursively justify their beliefs: repeated enough, the words and their worlds begin to sound natural, and then epistemically powerful, so that audiences trust the speakers who invoke those words and believe the knowledge from those conceptual worlds. 'Religion' is one powerful example of such a word that creates a naturalized category whose epistemic privilege makes it, as Barack Obama and Frederick Douglass observe in the epigraphs, a dangerous weapon.

'Religion' is not the synonym for spirituality or faith regularly assumed in common discourse; rather it describes an epistemic category. Treating religion as an epistemic category recognizes the concept's genealogy as an Enlightenment construct based on a Christian prototype, with discursively particular characteristics such as universality, plurality, cosmological explanation, and (sui generis) uniqueness. The concept we recognize today arises in the European Enlightenment from the combination of two seemingly contradictory logics: an imperialism seeking to dissolve borders, and an epistemology dualistically drawing borders. Religion, in turn, contributes to defining the epistemic borders of Enlightenment thought, and serves as a pretext for transcending borders to extend empires. The conceptual borders helped dissolve political borders by delineating institutions or practices that Europeans find sufficiently resemble their prototype of Christianity to be called 'religions.' Distinctions between conceptual and political realms are products of this epistemology, which pursues knowledge by erecting borders that often dualistically define one concept in contradistinction to the Other, such as civilization against barbarity or religion against the secular.

\section{Drawing and Dissolving Borders}


"With awe and wonder you look around, recognizing the preciousness of the earth,

the sanctity of every human being on the planet, the ultimate unity and interdependence of all beings-solos todos un paiz.”

\section{- Gloria Anzaldúa ${ }^{6}$}

Calling for a "spiritual activism," Anzaldúa envisions a universality that dissolves borders and engrains difference as part of an interwoven whole in ways that disclose the possibility of what she terms 'Borderlands.' The positive action she envisions occurring across cultures, transcending political borders, is premised on a mystical unity of all humans (and perhaps nonhumans) bound together by a divine 'sanctity' of belonging to one Earth. Unlike the unified and borderless universal spirituality Anzaldúa envisions, the universality of religion in modern discourse posits religion as an institution with many manifestations (religions) around the world and across time: a plurality divided by ideological borders. The prevalent narrative of Islam emerging as a religion in contradistinction to its prequel religion Christianity, which in turn arose from and defined itself against the original Abrahamic religion of Judaism displays bordermaking that defines the conceptual space within borders as separate religions. ${ }^{7}$ The naturalized view that Jews, Hindus, Buddhists, and Baha'is can be similarly defined in terms of belonging to 'religions' demonstrates a perceived universality of religion as a concept encompassing discrete but significantly similar instances of a universal form that are comparable enough to constitute a meaningful category. As a universal category, religion reinscribes the "dualistic thinking" Anzaldúa sees as engendering violence and conflict, because the universal category requires ideological borders to distinguish religions, not only defining one against another as Christianity defined itself against the heresies of Judaism, but also using dualistic divisions such as monotheistic against polytheistic, atheist versus theist, animist or materialist. 
'Religion' crystalizes in European Enlightenment epistemology as a concept in contradistinction to an Other. This contradistinctive self-definition imbues religion with power: religion is hegemonic "because it defined itself from the very outset in opposition to everything it judged not to be itself." " Thinkers defining themselves as 'religious' posited religion as contradistinctive to superstition, ${ }^{9}$ even though the Roman religio was not synonymous with the concept we now understand as religion. Rather, Carlon Barton describes it as an "anxious guilt" similar to scruples in contrast with the honor of pudor; the Romans' religiones "had nothing to do with Gods," but were rather "a matter of constant conscious and careful adjustments and manipulations." 10 Then 'Christian' Europeans defined their social organization and mores as 'civilized' in contrast to the 'barbarity' they observed abroad, insinuating moral and evolutionary hierarchies in which their own culture represented the prototypical apex of evolutionary and moral attainment. Hayden White calls this contradistinctive definition "the technique of ostensive self-definition by negation," and "civilizational identification by negative definition" perhaps the most common kind of cultural definition. Quoting St. Augustine on how irrelevant ideas are invoked, White suggests that such definitions indicate what the authors seek to defend. ${ }^{11}$ Faced with European definitions of the Other, we should ask what the definers sought to protect and justify.

The European construction of religions on a hierarchy of evolution offers a tantalizing promise to non-Europeans who see the potential for their societies to ultimately reach an enlightened state. W. E. B. Du Bois grappled with the European production of African fetishism as a religion, first endeavoring to defend it as source of African cultural pride and then critiquing the European "notion of the fetish as an ideological cover for relegating Africans to a subhuman status and 
justifying slavery." ${ }^{12}$ It takes a critical rejection of European norms and definitions, as Du Bois demonstrates, to free those societies from the imposed definitions that posit them as inferior.

Europeans defined religion as truth against heresy, orthodoxy against the heterodoxy, civilization against barbarity, the sacred against the profane. Defining a term in opposition to an Other through a false binary invites equivocation. If religion is 'not politics,' then it can occupy any and all positions that are 'not politics.' Religion can refer to personal belief or grounds for legal protection, a universal category uniting all humans, or an identity setting one group apart from another. Equivocation, in turn, suggests that if the term is so indistinct, it must be incomparable, sui generis. Equivocation lends itself to universalizing, since speakers can leverage various definitions or elements to suggest sufficient similarity to diverse phenomena. Religion's equivocal definition allows a range of similarities to cast a broad net of Wittgensteinian family resemblances based on similarities between religion's Christian prototype ${ }^{13}$ and practices or institutions that may share traits (such as deism, ritual, sacred texts, or belief in an afterlife) with Christianity but not each other, reinforcing the prototype's centrality. Though people use the term today as though it has always had the same meaning, 'religion' was premised on Christianity. Thus, Christianity's contrast to the Other strengthens Christianity's hegemony, and conceals its relationship to its 'daughter, ${ }^{14}$ religion, protecting a naturalized universalized view of religion.

Universality of religion is necessary for the European moral and evolutionary comparison of inferior non-European manifestations to a higher Christian prototype, because non-Christian 'religions' needed to be similar enough to fall within the same analytic category, and along the same imagined evolutionary path. Tomato Masuzawa characterizes educated late nineteenth century Europeans' (and North Americans') writings on comparative world religions as poorly 
researched and strongly motivated by the authors' "underlying interests" to complement Christianity, "justify the presumption of its superiority over all other religions," and provide "legitimacy to its missionary expansion." 15 In her view, not only do Europeans use religion to justify imperialism, but they also create systems of knowledge production to create stronger justifications. They develop and epistemology to justify the borders they draw between people and their imperial actions to transcend political borders.

European comparative religion defines the European institution against an inferior Other, using the figure of the barbarian to cast Africans as inferior, in religious and racialized terms. Douglass's choice of words in the epigraph above about Southern religion as "a justifier of the most appalling barbarity" is all the more powerful for its reversal of the civilization / barbarity binary to cast him, a freed black slave, as the civilized observer of white slaveholders' barbarity. One mechanism through which religion has gained sufficient authority to justify barbarity, which Fitzgerald describes in the epigraph, is the post-reformation construction of religion delineating a "conceptual and epistemological space" separate from politics and economics. Though precursors of contemporary 'religions' were hardly distinguishable from political entities, modern discourse frames 'religion' as a sphere distinct from 'the secular,' creating a rhetorical space imbued with certain epistemic, ethical, and ironically also political and economic privileges. Talal Asad locates the first universal definitions of religion in the seventeenth century, as discourse begins to distinguish these modes of knowledge production. Similarly to how Enlightenment epistemology defined religion in contradistinction to superstition, modern thought defines religion against the secular; as Asad argues, religion is a binary twin of the secular. ${ }^{16}$ The emergence of binary twin concepts define each other in opposition: secularism and 
religion, allowing in the eighteenth century for a private conception of religion as personal belief to overtake religion as a public source of power and truth. ${ }^{17}$

As Western Christianity comes to a private understanding of religion, it mirrors its private concept against a public ideal of secularism. ${ }^{18}$ Jason Josephson-Storm posits an alternative reading of how religion emerged and defined itself in contradistinction to other concepts, suggesting that discourse constructed both religion and science in opposition to superstition and magic, while secularization presumes that superstition belongs to religion. He describes the mutual reference and constitution of religion, science, and superstition as an "entangled formation of terms." ${ }^{19}$ As Anzaldúa rejects these entangled identity labels others apply to her as confusing her unitary self, the entangled terms of Enlightenment epistemology spheres of knowledge suggest not that the fields are confused, but rather that they are imperfect, imposing borders that do not fit the natural contours of epistemology's geography.

The similarly entangled reciprocal definition by contrast of the West defining itself against the 'savage' or 'primitive man' 20 enshrines an ethical hierarchy, ensuring that "cultural translation is inevitably enmeshed in conditions of power." ${ }^{21}$ Stuart Hall describes this construction of identity in power-laden contradistinction to a foreign Other as occurring "through the relation to the Other, the relation to what it is not, to precisely what it lacks." ${ }^{22}$ Tracing this identity construction of one's own group against an Other to the pre-Enlightenment, Geraldine Heng argues that medieval English communities set aside the Other as "not them." In this equation, religion functions as the dominant discourse, premising views of the Other on religious dichotomies of Christian in opposition to Muslim, though not with the understanding of religion that emerged in the following centuries. Medieval understandings of religion did not differentiate 
religion as a unique universal institution in the sense naturalized in contemporary discourse. Rather, religion was one of "a multiplicity of interlocking discourses." ${ }^{23}$ The construction of the Other elided religion and race, which Heng expresses with "race-as-religion," ${ }^{24}$ which applies racial borders as religious borders.

While the objects of knowledge may have become entangled and elided, the borders separating them from the subjects of knowledge were clear, particularly where they serve such dual purpose, and where they delineate powerful categories. Daniel Boyarin characterizes the modern view of religions as "fixed sets of conditions with well-defined boundaries." 25 Admission into those boundaries carries epistemic privilege signifying the knowledge that institution generates as more valuable than knowledge other sources produce. Kevin Schilbrack reinforces the metaphor of national borders as describing distinctions between religions, noting that both religions and nations are socially-constructed concepts whose continuation depends on discursive recognition of borderlines. ${ }^{26}$ I would add that the perpetuation of the concepts further depends on a European Enlightenment epistemology that recognizes borderlines as conceptually definitional and constitutive (e.g. recognizing a set of institutions within a category of 'religion' suggests that there exists a category of 'religions'), with such boundaries bringing the concepts into being in contradistinction to an Other on the opposing side of the border (e.g. religion defining itself against the secular). These two processes produce epistemic privilege. First, by constituting as well as defining the concepts (in a "conceptual and epistemological space"), borders help naturalize concepts, thereby giving credibility to the concepts and knowledge they produce or justify. Second, defining concepts in contradistinction to an Other gives the knowledge producers within the boundary discursive power in defining the Other. 
Naturalization occurs discursively. Through repeating phrases and contexts in which 'religion' appears, speaking of the borders between religion and not religion, language has naturalized an understanding of the term that modern discourse arbitrarily constructed. Discourse creates meaning, a critique that is applicable to religious studies: the field creates what it intends as the object of its study. Christianity, Islam, Jainism, Confucianism, and Voodoo belong to a categorical family because humans have spoken and written them together, because discourse has "juxtaposed" them, to borrow Michel Foucault's characterization, "in the non-place of language" to create a category. ${ }^{27}$ Foucault invokes Borges' "Chinese Encyclopaedia" example, ${ }^{28}$ which offers a taxonomy of animals at odds with European scientific conceptions of how to catalogue non-human members of our biological kingdom, exposing the arbitrariness of such classification, and suggesting that human language rather than objective fact produce the taxonomy. Hayden White proposes that at "the beginning of all understanding is classification, ${ }^{, 29}$ yet such an optimistic chronology omits the misconceptions classifications can inspire, and the epistemic privilege classification instills. Naturalizing the categorization of, for example, Buddhism as a religion implies that Buddhism resembles other religions, leading audiences to look in vain for a Buddhist Bible, Buddhist communion, or a Buddhist God.

As a naturalized concept, religion enjoys epistemic credibility, which produces one of religion's most powerful epistemic benefits in contemporary discourse: incontrovertibility. Knowledge and justifications arising from religion enjoy a protected status. Institutionally, there are legal protections for religion in the US and elsewhere, as evidenced by numerous examples of decisions protecting otherwise ethically questionable actions or stances on the basis that they are religiously motivated. ${ }^{30}$ On individual levels as well, audiences perceive religion as deserving “epistemic trustworthiness,” to use Miranda Fricker's term. ${ }^{31}$ For Fricker, epistemic 
trustworthiness falls into two categories: competence and sincerity, deriving from perceived authority, ethical virtue, race, class, gender, and other sources of prejudice. ${ }^{32}$ As a source, religion has high epistemic trustworthiness because it creates the worldview that makes it a dominant discourse, defines its own boundaries and oppositions, and reaffirms its discursive construction through its practice. Thus, an audience does not need to believe in a given religion to grant the religion epistemic privilege.

A deist audience believing religion achieves a connection to the transcendent might believe religion deserves epistemic privilege because it communicates divine knowledge humans should not question. Defending the Bible as incontrovertibly true because it is the word of God follows this logic. Agnostic audiences tend to assign religion epistemic privilege as a sui generis analytic category intrinsic to humanity or society. Viewing religion as sui generis absolves it of the standards to which comparable institutions would be held, while viewing it as an analytic category offers religion the formal recognition of an established knowledge system. Fitzgerald is concerned that a contemporary conception of religion as a sui generis, temporally and spatially universal, inherent, ontologically extant category is "essentialised as a generic category and used descriptively and analytically as though religion is something that unproblematically exists in the world, or alternatively as a heuristic category" whose interpretation is up to the scholar's (or imperialist's) discretion. ${ }^{33}$ Believing that religion is inherent to humanity implies that it deserves respect and epistemic privilege. So even for an agnostic, believing religion is intrinsic naturalizes religion, placing non-religious agents in a defensive Other category holding the burden to disprove epistemic reliability.

Shifting the burden of proof to non-religious epistemic agents belongs to perhaps the most discursively important source of epistemic privilege: from within epistemic boundaries, religion 
creates its own power by setting the terms of the discourse. The powerful want to protect their power; by controlling the discourse, they can discursively protect their power. Talal Asad presents the problem as an epistemic asymmetry in history-making, the process of society and academia imagining and presenting histories as fact rather than interpretation. Projecting a contemporary definition of religion selectively ${ }^{34}$ homogenizes humanity and history. Given that 'religion' is a Western (European) term, he worries that viewing non-Western society through a Western concept's lens — let alone writing non-Western history in Western terms - is misleading and reveals an epistemological power asymmetry: the West sets the terms of the debate, becomes the norm, unreciprocatingly expects others to assimilate to them, and belongs everywhere while others are "uprooted" when not in their historically limited "local place of origin." 35 The Western concept of religion's power in history-making skews the narrative. ${ }^{36}$ Universalization of a Western protestant concept inaccurately projects a homogenized view of human societies and history, constructs secularism as a foil for religion, and uses the field's rituals and scientific veneer to project objectivity.

As Asad critiques the asymmetry in epistemological power and the focus of history-making with the Christian West, Fitzgerald argues that asserting a modern conception of religion in studying the pre-modern or non-Western is "subordinating the whole history of humankind to our own presuppositions." ${ }^{37}$ Fitzgerald extends Daniel Dubuisson's critique that the Western construction of religion creates a world beyond which it cannot see ${ }^{38}$ in two ways: first to suggest that Western religion also prevents other societies from seeing beyond the West's construct. Second, the construction circularly reinforces itself by creating "a presumed reality in a way which validates our own practices, our own sense of who we are as enlightened moderns." This element "of our knowledge industry" normalizes and reinforces itself, for itself and as a justification for 
its hegemony ${ }^{39}$ and religion's epistemic privilege. The justificatory power of religion is crucial to Fitzgerald's treatment of definitions of religion in contradistinction to science, politics, and the public state. Each iteration of this religion / secular binary reflects the essential conceptual border as well as a way religion justifies access to power, which can indicate pretexts. For example, deploying (secular) military to protect (religious) missionaries negates the binary of and border between the religious and secular while exposing imperialist motives. ${ }^{40}$ Further, separation of church and state in the late eighteenth century US Constitution, marking "the full emergence of the modern idea of religion as the private exercise of a right granted by the state...defined by its separation from religion," initially appears to grant freedom of religion and reaffirm the epistemic border delineating religion while simultaneously giving the secular state power to protect religious practice, negating the binary separation and epistemic border to validate the state's power. ${ }^{41}$

\section{Borderline Excuse: Pretext}

"Why should we not form a secret society with but one object the furtherance of the British Empire and the bringing of the whole uncivilised world under British rule... Africa is still lying ready for us it is our duty to take it." - Cecil Rhodes $^{42}$

Rhodes is but one forthright example of Europeans justifying imperialism as an altruistic campaign to civilize a barbarian 'Other.' Europeans were the subject drawing the borders to define the theoretical and taxonomical framework. Europeans defined their civilization in contradistinction to the barbarian Other. Thus, their justification begs the question, fallaciously using circular reasoning: they created their own authority to defend their authority. The noblesse 
oblige characterizing Rhodes' nineteenth century missionary work as well as today's white savior complex humanitarian photo-op voluntourism rely on a comparative religious and cultural studies suggesting an evolutionary spectrum of religion or civilization. In addition to defining the civilized European subject against the barbaric non-European Other, modern imperialists and missionaries justify their superiority by claiming that European religion is more evolved than non-European 'religions.' Europeans constructed the purported universality of religion that would make the institutions comparable. Since Europeans defined 'religion' on a Christian prototype, Christianity would be definitionally closer to the prototype and therefore located higher on an imaginary evolutionary hierarchy. Europeans were defining their own terms, drawing conceptual borders delineating categories to justify them violating political borders in violent exploitation.

The justifications Rhodes and other European imperialists employ may spark skepticism: it may seem too convenient that purportedly altruistic missions serve the missionaries' economic and political interests so well. I want to suggest that the skepticism is well-placed and may expose a 'pretext.' In her 2003 Nobel Peace Prize acceptance lecture, Iranian lawyer and human rights activist Shirin Ebadi twice uses the term 'pretext' to describe governments and human rights opponents citing certain threats or ideals to validate violating human rights. First, Ebadi criticizes governments, presumably the United States, for exploiting 9/11 and the war on terror as a pretext, an instrument to justify their human rights violations: "some states have violated the universal principles and laws of human rights by using the events of 11 September and the war on international terrorism as a pretext." Two sentences later, she restates the problem describing the pretext as a "cloak" of justification, stating that illegitimate human rights restrictions and special courts "have been justified and given legitimacy under the cloak of the war on 
terrorism. ${ }^{43}$ Both statements imply that while governments offer the stated justification of fighting terrorism, it is a guise for ulterior motives. Second, Ebadi identifies an ideological pretext at play in justifications for violating human rights laws both by Western signatories of the Universal Declaration of Human Rights as well as by known human rights adversaries "under the pretext of cultural relativity," ${ }^{44}$ claiming that their non-Western cultures do not adhere to the same human rights as expressed in the Universal Declaration, and that their ethics are equally valid. Ebadi indicates that the pretext is a guise for other motivations, since the latter are "recognized opponents" of human rights, suggesting a prior opposition to human rights based on other motivating reasons.

Ebadi's application of 'pretext' is consistent with common parlance as well as the rhetorical understanding I propose of pretext as a discursive category of justification (e.g. for an action, ethical stance, or identity) that does not reflect a motivating reason, but rather serves to conceal true motivations or manipulate the audience through rhetorical appeal. Justifications are explanations a speaker offers to validate a proposition. Justifications may be thoughtless, impulsive, meaningless, irrelevant (a non sequitur), indecipherable, or otherwise lacking importance for our considerations. Differentiating between motivating and non-motivating justifications is not an arbitrary binary, but rather two possible answers to a pivotal question to pose when faced with a justification: is this justification a pretext? For a given ethical stance or action (the former possibly inspiring the latter), there are uncountable motivating reasons (what impels the actor, consciously or not, to hold a belief or act in a certain way) and finite justifications (what the agent asserts are the motivating reasons). Within that category of stated justifications, some fill the discursive role of reflecting motivating reasons, while others fill the role of pretext—stated as reasons, yet not reflecting motivating reasons, serving to conceal 
reasons or manipulate the audience. An agent is certainly unconscious of some reasons motivating her actions, stances, and identity formation, and may be unconscious of misrepresenting her motivating reasons when offering a pretext.

Recall again the epigraph from Frederick Douglass, which clearly distinguishes the "Christianity of Christ" from that of such "religionists." 45 The religion he describes is not a theoretical religion, but a specifically historically- and socially-situated religion of slaveholders, the "religion of the South." The specificity is important to understand the function: as a pretext for violence. Douglass writes that this religion is "a mere covering...justifier...sanctifier...dark shelter" for violent crimes. His terms are all synonyms for pretext, describing a stated justification that veils the true motivation in a more palatable façade: religion. That religion is a more acceptable source of justifications, and that religiously-based pretexts offer "the strongest protection" reflect religion's epistemic privilege. By negatively comparing religious slaveholders to non-religious slaveholders, he implies that the religious pretexts either allow or motivate the religious slaveholders to treat slaves more heinously. We might view the first reading as indicating an outward-focused pretext: slaveholders wish to treat slaves barbarically, and the religious pretext gives them license to do so without facing social condemnation. The second reading suggests an inward-focused pretext: slaveholders whose conscience would otherwise forbid them from treating slaves infernally feel their offenses vindicated by religious pretext authorizing their violence.

Douglass's point in this passage is that religion in the South provided slaveholders a pretext to violently mistreat slaves, a pretext they embraced. By the nineteenth century, the US had moved out of its colonial era yet colonial epistemologies still framed the country's perceptions of race. Douglass is describing vestiges of a colonial mentality that persist today and echo European 
imperial ideology observable around the world. David Chidester identifies one element of the colonial epistemology of Europeans in southern Africa that informed racist governing practices over centuries of white rule in the region: the stereotype of "primitive mentality." He describes how the "symbolic instrument of social segregation, economic exploitation, and political control" is identifiable "from justifications of nineteenth-century colonial domination to the implementation of twentieth-century apartheid." ${ }^{" 46}$ The racist misconceptions instrumental in helping imperialists justify colonizing the Americas and Africa, and in providing the ethical framework to support centuries of legalized slavery and did not end with apartheid. It would be a mistake to shake our heads at the intellectual crimes of past centuries when the misconceptions continue to inform our worldviews.

To illustrate how European Enlightenment epistemology's conception of religion creates borders that serve as grounds for pretext, I'd like to offer a contemporary example. In the veiling discourse, specifically around the niqab (lower face veil), European and non-European powers alike use a western view of religion to justify legislating women's bodies as vessels representing their 'culture' delineated by that religion, seeking to preserve an imagined racialized and gendered cultural purity.

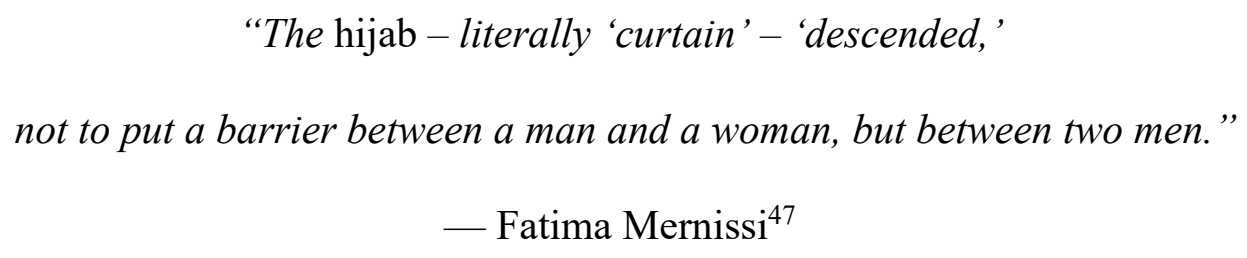

Anxious to consummate his marriage to Zaynab while wedding guests enjoyed the feast in the same room, the Prophet directed a pointed comment about rude guests, and hung a hijab (curtain) between the bed and his companions (male followers). Fatima Mernissi's retelling of 
the hijab's first use emphasizes the exclusion of men, rather than seclusion of women as the original intent of the 'hijab,' which now applies generally to head scarves. Mernissi questions how a story about hospitality and etiquette around male-male relationships in the home has evolved into a directive for women to cover themselves in public, and whether Qur'anic references to veiling are mandates for women today to veil. These questions are important because contemporary justifications for requiring women to veil focus on four Qur'anic passages mentioning women's interactions with unrelated men, ${ }^{48}$ though as Anne-Sofie Roald concludes in her search for a theoretical Qur'anic basis for the veil, there is "no Koranic evidence that wearing the veil is an Islamic obligation." 49

Mernissi regards the Qur'an's original context as crucial to textural interpretation: only when considering women's bodies "as symbolic representation[s] of community - can we understand what the hijab signified in year 5 of the Hejira", nearly 14 centuries ago, ${ }^{50}$ and how veiling shifted from being a practice for the Prophet's wives, to distinguishing freed women from slaves, ${ }^{51}$ to some societies mandating it for all women. In the time of the Prophet, the Qur'an did not yet exist to be a holy and statutory text for Islam, which was not considered a 'religion,' and particularly not in the post-Enlightenment sense in common discourse today. At that time, the Prophet's words carried epistemic weight, at least with his followers, yet it took centuries of textual interpretation of the Qur'an and Hadith for passages about the Prophet's wives veiling ${ }^{52}$ to be viewed as applying to common women. The geographical context in which we interpret those passages is equally relevant. Islamic societies fear globalized western values influencing their culture, while European societies fear of immigrant culture, both fears fostering exclusionary polities protecting their culture. 
While some Islamic societies cite scriptural passages to justify mandating veiling, neocolonial European societies use feminism and secularism to justify legislating women's dress. ${ }^{53}$ Recent European niqab bans cite secular ideals to forbid symbols of secularism's "binary twin," 'Religion.' France was the first European country to impose a fine for veiling, offering three justifications: social cohesion, security concerns, and their secular constitution. In the decade since, the Netherlands, Bulgaria, Latvia, Austria, and Denmark have instituted fines for face coverings, while in Belgium, women wearing face coverings also risk jail time. ${ }^{54}$ Both sides fear (and fear their desire for) the Other, exoticizing women who represent the Other, yet relegating veiled women to a private, passive, metaphorical, and concealing space. The oppositional yet analogous positioning of veiled women in each society mutually enforces the other's assertions of their value system, amplifying the very movement each seeks to resist. Situating women in subaltern space through the veil turns women into vessels, proxy containers for other debates, and distracting from actual issues. The two perspectives are oppositional yet analogous, complementarily conflicting approaches that mutually compound and exacerbate one another. "The irony," Mernissi observes, "is that Muslim and European theories come to the same conclusion: women are destructive to the social order-for Imam Ghazali because they are active, for Freud because they are not." 55 She is referring to the fear that women's sexual potency threatens the social order. In Islamic thought, women's passive role obeying men creates a tension with their active sexuality, ${ }^{56}$ while European society views it as passive. The oppositional approaches are nonetheless analogous: both posit women as essentially passive, with dangerous sexuality. ${ }^{57}$

Veiling a woman, extending the private sphere to separated her from the public sphere, precludes her full social involvement. A central justification in European anti-niqab campaigns is that 
covering the face prevents women's full public participation. ${ }^{58}$ Even self-identified Islamists argue that "when a woman wears a [niqab] it is difficult for her to make contact with the rest of society. ${ }^{\circ 9}$ Such exclusion is central to the original intent of hijab, yet inconsistent with modern democratic ideology, as well as with Islamic spiritual ideals. A connection with the divine requires bare face and hands, and that the supplicant lift an uncovered face to the heavens $\left(d a^{\prime} w a\right)$, thus the niqab impedes its ostensible intent of making women more pious. Veiling is self-stultifying in three further significant theoretical ways. First, the Islamic debate sexualizes women whose sexualization it seeks to prevent. ${ }^{60}$ Second, it undermines the veil's pious symbolic significance. Third, European niqab bans claim to draw women into the public sphere, yet confines those women to the home.

The primary justification for banning niqab is its religious symbolism, unacceptable in secular society. However, enforcing the ban excludes niqabis from secular society by punishing them for being in public. The justification that a niqab ban protects women in Europe who want to be modern and uncovered from their traditional families' tyranny illustrates how local and neocolonial societies are acting oppositionally yet analogously. Banning niqab replicates enforcing niqab: whether the patriarchal figure telling the woman what (not) to wear is the state or an Imam, the action is paternalistic. Prioritizing European dress over Islamic dress enforces assimilation, dictating that women conform to dominant society, while local societies respond to globalized western culture by forcing women to veil. Each responds to a perceived threat from the Other by dictating women's dress, imbuing women with the culture's mores. In both cultural contexts, the primary justification for legislating niqab is self-defeating, which suggests that these arguments are political pretexts, with other motivations underlying the respective movements. 
1920s Turkey and Iran offer intriguing cases of Muslim-majority countries seeking to 'modernize' by rejecting veiling. Turkish President Kemal Atatürk opposed the veil (niqab and hijab) as a symbol of barbarity marking Turkey as an inferior Other. He argued that veiling did not befit a civilized nation, proclaiming it "a spectacle that makes the nation an object of ridicule. ${ }^{\prime 61}$ Atatürk's contemporary, the Iranian Reza Shah Pahlavi, used similar language to describe veiling as an uncivilized "symbol of backwardness," condemning the practice as a source of shame for Iran. Atatürk and Shah were driven to conform to European societies' standards out of an envious desire to modernize combined with fear of inferiority and otherness. The non-European powers imitating Europe were afraid that they, the men, would be subaltern. They extended the Enlightenment epistemology logic of defining the one in contradistinction to the Other from race to gender, positing the woman as the barbarian Other against whom they could define their civility: gender became the border, though religion was still the pretext. ${ }^{62}$

Across cases, from Islamic countries mandating and European countries banning the niqab, to Turkey and Iran seeking to modernize through secularism, the sexist inconsistent enforcement and prohibition of women's religious head coverings but not men's — such as the Jewish kippah, Sikh pagri, or even the Muslim kufi—indicates that religion is serving as a pretext for controlling women's bodies. In Europe, Muslim women are in a particularly vulnerable position because they belong to the religion of the Other: Catholic nuns may retain their veils, revelers their carnival masks, and teenagers their hoodies. Legislating veiling is superficially sexist by applying different standards to women than men. A sexism of desire is evident in the focus on women's sexually potent bodies and exoticized otherness. A more complex sexism lies in how societies disguise their motives by focusing campaigns on women. 
European societies respond to fear of the Other by attempting to legislate religion, which casts religion as the central place of resistance against neocolonial powers, and both sides look to women's bodies as symbolic of religious space. What European powers attempt to ban is not an item of clothing, but rather what it symbolizes: the religious Other. What Islamic societies attempt to enforce through the veil is symbolic observation of religion. The European Court of Human Rights recognizes the hijab as a "powerful external symbol" with a potential "proselytising effect," a symbol at odds with "the message of tolerance, respect for others, and above all, equality and non-discrimination." ${ }^{63}$ The court objects to hijab not as clothing, but rather as a symbol or religion. Neither veiling nor unveiling is inherently problematic; the niqab has no essential positive nor negative value. What is objectionable is when societies determine women's actions and deprive women of agency. Both justify denying women's agency by appealing to ostensibly transcendent authorities: Islamic powers appeal to the Qur'an (representative of a modern conception of religion), while European and modernizing Islamic powers to appeal to religion's binary twin, secularism (laïcité). So long as European Enlightenment epistemology places religion above the law, attempts to legislate religion are invalid, yet societies can legislate women through their clothing, under the veil of religion.

Confronted with the intercultural interface of Islamic and European societies coming into contact in a Borderland, both sides position women as vessels while the Other society's challenge heightens their need to defend that cultural practice. Each aims to protect their cultural mores by protecting women from the other side's onslaught. Mernissi addresses how, in a modern context, Islamic powers tout the veil not as a means of partitioning women off from God, but rather from progress, "[p]rotecting women from change by veiling them and shutting them out of the world has echoes of closing the community to protect it from the West." ${ }^{94}$ Yet European societies' 
appealing modernism compounds the internal cycle of reform and reaction, wrapping society even more tightly around women as vessels, dehumanizing the women in a way that parallels how European Enlightenment anthropologists dehumanized the 'barbarian' Other in the process of justifying imperial subjugation of a vessel for Christian conversion.

\section{Finding the liberatory potential}

'Religion' as Frederick Douglass and Barack Obama use the term in the epigraphs, is far from Anzaldúa's cosmological view of religion as an epistemology, ${ }^{65}$ whose diverse manifestations come together in the concept of Borderlands/La Frontera where tensions and hybridity yield transformative liberatory and epistemic potential. ${ }^{66}$ The specific examples of a naturalized conception of 'religion' in this article represent oppressive rather than liberatory institutions and ideologies, ones serving to manipulate rather than generate knowledge. Boundary zones, as Anzaldúa argues, are rich with epistemic potential; yet the border is also a dangerous source of power. Drawing on historical and contemporary examples, I have sought to provide a framework for identifying how the Enlightenment European construction of 'Religion' at once erects and dissolves borders, allowing actors to exploit religion's epistemic privilege to manipulate those borders and justify violence and dehumanization.

To identify the conceptual framework in such a case, look for invocation of religion as a universal, plural, sui generis, cosmologically explanatory institution. Where a specific 'religion' is invoked, pay attention to how the ideology or practice is portrayed so as to highlight parallels with Christianity, such as canonical texts, rituals, or belief in something resembling God. Consider how dualities serve to naturalize and mutually reinforce concepts (as in the divide between religion and the secular), or to privilege a dominant epistemology (for example in 
describing the civilized against the barbarian, or identities of gender, sexuality, and race). Then consider how those dualities reinforce national or cultural borders (as in the imperial one against the colonized Other or women as vessels for culture), and how religion as a concept serves as a border, whether geographic or epistemic.

To evaluate the justificatory logic, consider justifications from other epistemically comparable sources, such as tradition or literature; would a justification based in such a source be as powerful, or does the appeal to religion carry more power. Look for justifications that could just as well originate from another source and consider whether they are exploiting the relatively high trust of knowledge arising from the Enlightenment European concept of religion. When Frederick Douglass writes that religion offers slaveholders "the strongest protection" for their violence, he is describing the epistemic privilege that religion enjoys. When audiences assign knowledge deriving from a particular source more authority on the basis of that source, then the source enjoys epistemic privilege, granted through the audience's perception of the source's epistemic trustworthiness.

The dominant conception of religion enjoys extreme trustworthiness, incontrovertibility. "Whenever morality is based on theology," Ludwig Feuerbach writes, "wherever the right is made dependent on divine authority, the most immoral, unjust, infamous things can be justified and established...to derive anything from God, is nothing more than to withdraw it from the test of reason, to institute it as indubitable, unassailable, sacred, without rendering an account why." ${ }^{967}$ Feuerbach expresses how an appeal to religious justification protects the argument from the standards to which non-religious arguments are held, for religion enjoys epistemic incontrovertibility. Appealing to God as the foundation for something — say, a justificationserves the epistemic function of revoking the requirement of reason. The appeal to God turns the 
justifications into something indubitable, inviolable, and holy, Feuerbach asserts. This incontrovertibility is an element of epistemic privilege, and its contextualization in a discussion of religious justification highlights the secondary power of incontrovertibility: increased justificatory weight. Not only can the audience not question the source of authority, but the pretext deriving from that authority is likewise protected.

To distinguish how religion validates pretexts, consider how religion's epistemic trustworthiness or even incontrovertibility serves to shield the justification from skepticism. Feuerbach expresses concern that religion produces not true motivations, but rather false guises that religion's constructed ethics protect. Feuerbach describes the rhetorical device of pretext, in the context of using religion to justify wronging another human: "[t]he real cause is converted into an impersonal means, a merely conceptual, imaginary cause usurps the place of the true one." ${ }^{98}$ The 'real cause' is what I call the 'motivating reason' (for an action, ethical stance, or identity), while the 'merely conceptual, imaginary cause' is what I call 'pretext.' Both phrasings retain the implication that an agent strategically deploys a lie to appeal to an audience's epistemic biases. Given those biases, the audience assigns justifications — whether motivations or pretextsincreased justificatory weight.

Where Douglass names religion as "justifier of the most appalling barbarity," ${ }^{69}$ Feuerbach considers 'morality' premised on theology the source and pretext for "the most immoral, unjust" and dishonorable things. Though they use different images, I believe both Feuerbach and Douglass refer to the same entity, a discursive construct that grants ethical authority. For Douglass, authority is rooted in southern society, while for Feuerbach, theology and divinity grant authority to the constructed morality or ethics. The circular reasoning Feuerbach scorns parallels the circular reasoning I critique above: the reason for accepting the authority of religion 
cannot logically depend on the authority of religion. Morality of the divine cannot depend on divinity's morality, to use Feuerbach's objects, for those are two versions of the same genitive. That incontrovertibility is why 'Religion' as an epistemic category justifies powerful borders between and violence against the religious Other, from the proto-Globalization of European imperialism to contemporary neo-imperialism such as niqab bans.

European Enlightenment epistemology's two contradictory logics producing 'religion' as the concept we recognize today are an epistemic drive to construct borders and an imperialist desire to transcend borders. This epistemology's dualistic logic generated borders-between spheres of power (such as politics versus family), and (civilized versus 'barbarian') people that power influences - in order to justify their political-border-transcending violence in defining their civilization against the 'barbarian' Other, while exploiting the Other's labor and resources. European empires planted their flags around the globe in the name of Christendom, a kingdom predicated on bringing 'heathen' souls into a more evolved fold, elevating them from a base barbarian religion to the highest form of religion, the one true commonality of huma kind expressing the deepest human impulses and possessing the greatest moral value. This framing of 'Religion' strengthens the borders it creates due to epistemic privilege as universal, implicit, and constitutive (think cogito, ergo sum) above other mechanisms of division. These Enlightenment European values make knowledge a precondition for being, premising ontological status on epistemic value. To be as a human, one must exhibit justified true belief, a view promoting the European civilizing mission, for bringing 'true' belief to 'heathens' is to grant them worth as human beings.

'Religion' as an epistemology serves as a justification for erecting powerful privilege-justifying borders between people, and those borders justify violence from individual to transnational 
levels. In the case of veiling, religion justifies strengthening borders between a binary conception of men and women on an individual identity level, to borders between a mythical pure culture and the threatening Other on a societal identity level. As scholars and as citizens, we must be attentive to how the category of 'Religion' serves as an incontrovertible and pretextual source of justification for injuring the Other, so that instead, encounters with the Other can achieve the epistemic and liberatory potential of the Borderlands Anzaldúa envisions.

\footnotetext{
${ }^{1}$ Many thanks to Daniel Boyarin for the many afternoon conversations that shaped the theoretical basis of this essay, as well as my world view. Thank you, Nazila Ghanea-Hercock, for your Women, Religion, and Human Rights module. Thanks also to the generously helpful participants of events where I have presented this material, including the Trinity College Dublin Feminist Philosophy Reading Group, the 2020 Language and Violence: Literary Mediations in the Age of the Anthropocene conference at the Universidade de Vigo, 2019 Patriarchy \& Political Theology Workshop at Villanova University, 2018 Society for the Scientific Study of Religion Meeting and McGill-CREOR Conference Religion and Violence, 2017 Second World Congress on Logic and Religion, and 2015 Politics of Attachment conference at the Amsterdam School for Cultural Analysis. I am grateful to Marie Skłodowska-Curie Actions and the Trinity College Dublin Long Room Hub Arts \& Humanities Research Institute for cofunding the postdoctoral fellowship that allowed me to write this article.

${ }^{2}$ Gloria Anzaldúa, "La prieta." This bridge called my back, 2nd edition, ed. Cherríe Moraga and Gloria Anzaldúa (Watertown, Mass, Persephone Press, 1983), 205.

${ }^{3}$ Timothy Fitzgerald, Discourse on Civility and Barbarity (New York: Oxford University Press, 2010), 68.

${ }^{4}$ Cathleen Falsani, "Transcript: Barack Obama and The God Factor Interview," Sojourners, https://sojo.net/articles/transcript-barack-obama-and-god-factor-interview (Accessed April 29, 2018).

${ }^{5}$ Frederick Douglass, Narrative of the Life of Frederick Douglass (New York: Millennium Publications, 2014), 68.

${ }^{6}$ Gloria Anzaldúa, "now let us shift...the path of conocimiento...inner work, public acts," this bridge we call home: radical visions for transformation, eds. Gloria E. Anzaldúa and AnaLouise Keating (New York: Routledge, 2002), 558.

${ }^{7}$ See notably Daniel Boyarin's argument that delineating borders between Christianity and (heretical) Judaism created the concept of 'religion.'

Daniel Boyarin, Border Lines (Philadelphia: University of Pennsylvania Press, 2010).
} 
${ }^{8}$ Daniel Dubuisson, The Western Construction of Religion (Baltimore: Johns Hopkins University Press, 2003), 14.

${ }^{9}$ Francois Le Vaillant suggests that the conception of superstition emerged from a conception of religion. David Chidester, Savage Systems (Charlottesville: University of Virginia Press, 1996), 235.

${ }^{10}$ Carlin Barton and Daniel Boyarin, Imagine No Religion (New York: Fordham University Press, 2016), $38,23,16,37$.

${ }^{11}$ Hayden White, Tropics of Discourse: Essays in Cultural Criticism (Baltimore: The Johns Hopkins University Press, 1978), 150-3.

${ }^{12}$ David Chidester, Empire of Religion (Chicago: University of Chicago Press, 2014), 11.

${ }^{13}$ Benson Saler, Conceptualizing Religion (New York: Berghahn Books, 2000), Chapter 6.

${ }^{14}$ Dubuisson, The Western Construction of Religion, 9.

${ }^{15}$ Tomoko Masuzawa, The Invention of World Religions (Chicago: University of Chicago Press, 2005), 72-3.

${ }^{16}$ Chidester notes how the 1884-5 Berlin Conference reversed previous colonial conversion practices of promising religious tolerance of the African societies they divvied up, which speaks to how secularism became a tool of imperial control by changing the terms of religion.

Chidester, Empire of Religion, 19-20.

${ }^{17}$ Fitzgerald makes a similar argument. Fitzgerald, Discourse on Civility, 13, 231-2.

${ }^{18}$ Talal Asad, Genealogies of Religion (Baltimore, MD: Johns Hopkins University Press, 2009), 27-8.

${ }^{19}$ Jason A. Josephson-Storm, The Myth of Disenchantment: Magic, Modernity, and the Birth of the Human Sciences (Chicago, University of Chicago Press, 2017), 11.

${ }^{20}$ Asad, Genealogies of Religion, 19-20. See also Chidester, Empire of Religion.

${ }^{21}$ Asad, Genealogies of Religion, 198.

${ }^{22}$ Stuart Hall, “Introduction: Who Needs 'Identity'?” in Questions of Cultural Identity, eds. Stuart Hall and Paul du Gay (London: Sage Publications, 1996), 5.

${ }^{23}$ Geraldine Heng, The Invention of Race in the European Middle Ages (Cambridge: Cambridge University Press, 2018), 27.

${ }^{24}$ Heng, The Invention of Race, 149.

${ }^{25}$ Daniel Boyarin, The Jewish Gospels: The Story of the Jewish Christ (New York: The New Press, 2012), 8 .

${ }^{26}$ Kevin Schilbrack, "The social construction of 'religion' and its limits," Method \& Theory in the Study of Religion, 2013. 24(2): 109.

Imagine the political potency of refusing to recognize borders as ontologically extant entities.

${ }^{27}$ Michel Foucault, The Order of Things: an Archaeology of the Human Sciences (New York: Vintage Books, 1973), xvii.

${ }^{28}$ Foucault, Order of Things, xv.

${ }^{29}$ White, Tropics of Discourse, 22. 
${ }^{30}$ For example, the Supreme Court decisions Wisconsin v. Yoder (1972) exempted Amish youth from mandatory school attendance on the basis of their religion's expectations, Church of the Lukumi Babalu Aye v. City of Hialeah (1993) overturned laws against animal sacrifice to allow Santeria practitioners to sacrifice animals, Gonzales v. O Centro Espirita Beneficiente Uniao do Vegetal (2006) allowed the use of the otherwise illegal drug hoasca for "religious purposes," and Burwell v. Hobby Lobby Stores, Inc. (2014) exempted a for-profit corporation from regulations to which the corporation's owners objected on religious grounds.

${ }^{31}$ Miranda Fricker, Epistemic Injustice: Power and the Ethics of Knowing (Oxford: Oxford University Press, 2007), 45.

${ }^{32}$ Sincerity is an ethical value for Fricker, based on personal emotional response, a socially constructed value.

Fricker, Epistemic Injustice, 45, 72, 76119.

${ }^{33}$ Fitzgerald, Discourse on Civility, 68-9.

${ }^{34}$ Asad notes that power constructs and exploits difference and ambiguity to its advantage, selecting where best to project unity, and where divergence. Asad, Genealogies of Religion, 16-7.

${ }^{35}$ Asad, Genealogies of Religion, 8, 200, 273.

${ }^{36}$ Asad, Genealogies of Religion, 24.

${ }^{37}$ Fitzgerald, Discourse on Civility, 69.

${ }^{38}$ Dubuisson, The Western Construction of Religion, 38.

${ }^{39}$ Fitzgerald, Discourse on Civility, 69.

${ }^{40}$ Fitzgerald, Discourse on Civility, 136-7.

${ }^{41}$ Fitzgerald, Discourse on Civility, 278.

${ }^{42}$ Cecil Rhodes, “Confession of Faith,” 1877.

${ }^{43}$ Shirin Ebadi, “The Nobel Peace Lecture for 2003," Peace Research 36, no. 1 (May 2004)), 20.

${ }^{44}$ Ebadi, "Nobel Peace Lecture," 20.

${ }^{45}$ Douglass, Narrative of the Life of Frederick Douglass, 68.

${ }^{46}$ Chidester, Savage Systems, 232-3.

${ }^{47}$ Fatima Mernissi, The veil and the male elite: a feminist interpretation of women's rights in Islam (Cambridge, Mass.: Perseus Books, 1991), 85.

${ }^{48}$ Qur'an 24:30-1, 33:30-3, 33:53, and 33:59.

${ }^{49}$ Anne Sofie Roald, Women in Islam: the Western experience (London: Routledge, 2001), 256.

${ }^{50}$ Mernissi, The veil and the male elite, 99.

${ }^{51}$ In the hadith, Umar directs a woman "to remove" her hijab, because she is a slave, while the hijab is "for free believing women to wear" (Roald, Women in Islam, 275, citing al-Albani).

${ }^{52}$ Qur'an 33:30-3, 33:53, and 33:59.

${ }^{53}$ Mernissi and Roald acknowledge and rebut these justifications, yet both theorists tend to treat them as legitimate motivations, rather than distractions, rather than pretexts. 
${ }^{54}$ The Belgian police introduced the interdict le règlement vise l'interdiction de se présenter dans l'espace public masqué ou déguisé in 2004, followed by the French bill, Loi 2010-1192, interdisant la dissimulation $d u$ visage dans l'espace public, and the Catalan Government's anti-niqab legislation in 2010. Then the Netherlands passed a similar bill passed in 2012. Sweden banned the niqab (but not headscarf) in schools, arguing that it undermines gender equality.

Titia Loenen \& Jenny E. Goldschmidt, eds. Religious Pluralism and Human Rights in Europe: Where to Draw the Line? (Antwerp: Intersentia, 2007), 138.

${ }^{55}$ Fatima Mernissi, Beyond the veil : male-female dynamics in modern Muslim society (London: Saqi Books, 2003), 498.

${ }^{56}$ Fatima Mernissi, “The Meaning of Spatial Boundaries," Feminist Postcolonial Theory (Edinburgh: Edinburgh University Press. 2003), 498.

${ }^{57}$ Reina Lewis \& Sara Mills, Feminist Postcolonial Theory (Edinburgh: Edinburgh University Press, 2003), 15.

${ }^{58}$ Sénat, 2010. Rapport du Sénat $N^{o}$ 669. [online] Available at: <http://www.senat.fr/rap/109-699/1096991.pdf>

${ }^{59}$ Roald, Women in Islam, 289.

${ }^{60}$ Religious justifications do not necessarily translate to personal justifications. Naema Tahiri suggests that women choose to veil as a license to sexualise themselves, as "halal-flirting" (Loenen \& Goldschmidt, Religious Pluralism, 159).

${ }^{61}$ Gaurav Gajanan Desai \& Supriya Nair, Postcolonialisms: An Anthology of Cultural Theory and Criticism (New Brunswick, New Jersey: Rutgers University Press, 2005), 333, quoting Ataturk's speech at Kastamonu.

${ }^{62}$ More recently, Muslim-majority countries have instituted niqab and even hijab bans, citing justifications including secular ideals in the case of Egypt, though also public safety in the case of Algeria. Some non-Muslim-majority countries in Africa have banned the niqab, purportedly as antiterrorist measures.

${ }^{63}$ Loenen \& Goldschmidt, Religious Pluralism, 133, 134.

${ }^{64}$ Mernissi, The veil and the male elite, 99.

${ }^{65}$ Marcus Embry, "Cholo Angels in Guadalajara: The Politics and Poetics of Anzaldúa's Borderlands/La frontera," Women \& Performance: A Journal of Feminist Theory, 8:2 (1996), 101.

${ }^{66}$ Gloria Anzaldúa \& AnaLouise Keating, eds., The Gloria Anzaldúa Reader (Durham, NC: Duke University Press, 2009), 319.

${ }^{67}$ Ludwig Feuerbach, The Essence of Christianity, trans. Marian Evans (George Eliot) (New York: Calvin Blanchard, 1855), 344-5, italics in the translation.

${ }^{68}$ Feuerbach, The Essence of Christianity, 269.

${ }^{69}$ Douglass, Narrative of the Life of Frederick Douglass, 47. 